\title{
PENYULUHAN TENTANG DIARE DI SMA N 2 KUMAI \\ ${ }^{1}$ Yayat Supriyatna \\ ${ }^{1}$ Stikes Borneo Cendekia Medika Pangkalan Bun \\ Email : $\underline{\text { Yayatsupriyatna@gmail.com }}$
}

\begin{abstract}
ABSTRAK
Penyakit diare masih merupakan masalah kesehatan masyarakat di negara berkembang seperti di Indonesia. Berdasarkan riset yang dilakukan oleh Departemen Kesehatan RI pada tahun 2007, diare menduduki peringkat ketigabelas sebagai penyebab kematian semua umur dengan proporsi sebesar 3,5 persen. Sedangkan berdasarkan kategori penyakit menular, diare menduduki urutan ketiga penyebab kematian setelah Pneumonia dan TBC. Penyebab utama kematian akibat diare adalah tata laksana yang tidak tepat baik di rumah maupun di sarana kesehatan. Untuk menurunkan kematian karena diare perlu tata laksana yang cepat dan tepat. Diare dapat berakibat fatal apabila penderita mengalami dehidrasi akibat kehilangan banyak cairan dari tubuh
\end{abstract}

Kata Kunci : Penyuluhan, Diare

\section{ABSTRACT}

Diarrheal disease is still a public health problem in developing countries such as Indonesia. Based on research conducted by the Indonesian Ministry of Health in 2007, diarrhea was ranked thirteenth as a cause of death for all ages with a proportion of 3.5 percent. Meanwhile, based on the category of infectious diseases, diarrhea is the third cause of death after pneumonia and tuberculosis. The main cause of death due to diarrhea is improper management both at home and in health facilities. To reduce mortality due to diarrhea, it needs fast and precise management. Diarrhea can be fatal if the sufferer is dehydrated due to losing a lot of fluids from the body

Keywords : Counseling, Diarrhea 


\section{PENDAHULUAN}

Penyakit diare masih merupakan masalah kesehatan masyarakat di negara berkembang seperti di Indonesia. Berdasarkan riset yang dilakukan oleh Departemen Kesehatan RI pada tahun 2007, diare menduduki peringkat ketigabelas sebagai penyebab kematian semua umur dengan proporsi sebesar 3,5 persen. Sedangkan berdasarkan kategori penyakit menular, diare menduduki urutan ketiga penyebab kematian setelah Pneumonia dan TBC. Dari data tersebut, golongan usia yang paling banyak mengalami diare adalah balita dengan prevalensi sebesar 16,7 persen.

Kejadian Luar Biasa (KLB) diare juga masih sering terjadi, dengan CFR yang masih tinggi. Pada tahun 2008 terjadi KLB di 69 Kecamatan dengan jumlah kasus 8133 orang, kematian 239 orang (CFR 2,94\%). Tahun 2009 terjadi KLB di 24 Kecamatan dengan jumlah kasus 5.756 orang, dengan kematian 100 orang (CFR 1,74\%), sedangkan tahun 2010 terjadi KLB diare di 33 kecamatan dengan jumlah penderita 4204 dengan kematian 73 orang (CFR $1,74 \%$.)

Penyebab utama kematian akibat diare adalah tata laksana yang tidak tepat baik di rumah maupun di sarana kesehatan. Untuk menurunkan kematian karena diare perlu tata laksana yang cepat dan tepat. Diare dapat berakibat fatal apabila penderita mengalami dehidrasi akibat kehilangan banyak cairan dari tubuh. Oleh sebab itu diare tidak boleh dipandang sebelah mata walaupun kondisi ini umum terjadi. Tujuan dalam kegiatan penyuluhan ini adalah memberikan pendidikan kesehatan kepada masyarakat penyakit diare sehingga seluruh siswa dapat mengatasi dengan tepat bila terjadi diare. Adapun manfaat dari pelaksanaan kegiatan ini antara lain: agar seluruh, siswa memahami tentang penyakit diare, mengetahui penyebab kejadian diare dan dapat mengatasi dengan tepat bila tejadi diare

\section{TINJAUAN PUSTAKA}

\section{A. PENGERTIAN}

Diare merupakan kondisi yang ditandai dengan encernya tinja yang dikeluarkan dengan frekuensi buang air besar (BAB) yang lebih sering dibandingkan dengan biasanya. Biasanya diare hanya berlangsung beberapa hari, namun pada sebagian kasus memanjang hingga berminggu-minggu. Bila tidak mendapatkan penanganan yang tepat, dapat berakibat fatal.

\section{B. PENYEBAB DIARE}

Pada umumnya, diare terjadi akibat konsumsi makanan atau minuman yang terkontaminasi bakteri, virus, atau parasit. Penyebab diare pada orang dewasa dan anakanak umumnya adalah infeksi usus. Infeksi usus bisa terjadi ketika mengonsumsi makanan atau minuman yang kotor dan terkontaminasi. Mikroorganisme yang sering menyebabkan infeksi usus adalah bakteri, parasit, dan virus seperti norovirus dan rotavirus.

Diare juga bisa timbul akibat faktorfaktor berikut ini, seperti efek samping obatobatan tertentu, faktor psikologi, misalnya 
gelisah, dan mengonsumsi minuman beralkohol dan kopi yang berlebihan.

\section{GEJALA}

Gejala diare bermacam-macam, dimulai dari yang hanya merasakan sakit perut singkat dengan tinja yang tidak terlalu encer hingga ada yang mengalami kram perut dengan tinja yang sangat encer. Pada kasus diare parah, dapat disertai demam dan kram perut hebat.

\section{PENCEGAHAN}

Diare bukan saja berdampak kepada diri penderita, tapi juga berpotensi menyebar, terutama kepada anggota keluarga. Oleh sebab itu, diare sebaiknya dicegah mulai dari kontak pertama hingga penyebarannya.Berikut adalah langkahlangkah pencegahan terkena diare akibat kontaminasi:

1. Mencuci tangan sebelum makan.

2. Menjauhi makanan yang kebersihannya diragukan dan tidak minum air keran.

3. Memisahkan makanan yang mentah dari yang matang.

4. Utamakan bahan makanan yang segar.

5. Menyimpan makanan di kulkas dan tidak membiarkan makanan tertinggal di bawah paparan sinar matahari atau suhu ruangan.

6. Jika tinggal satu rumah dengan pederita diare, pastikan penderita menghindari penggunaan handuk atau peralatan makan yang sama dengan anggota keluarga lainnya.
7. Membersihkan toilet dengan disinfektan tiap setelah buang air besar.

8. Tetap berada di rumah setidaknya 48 jam setelah periode diare yang terakhir.

9. Mencuci tangan setelah menggunakan toilet atau sebelum makan dan sebelum menyiapkan makanan.

\section{E. PENATALAKSANAAN}

Diare yang parah dapat berujung kepada dehidrasi. Dehidrasi memiliki konsekuensi yang fatal dan berpotensi merenggut nyawa penderita, terutama jika terjadi pada anak-anak. Hal ini karena ketahanan tubuh anak-anak terhadap dehidrasi jauh lebih rendah dibandingkan orang dewasa. Maka dari itu, orang tua disarankan untuk mewaspadai tanda-tanda dehidrasi pada anak. Penderita juga disarankan untuk meminum banyak cairan selama diare masih berlangsung.

Oralit dapat diminum untuk menghindari dehidrasi, tetapi konsultasikan pemakaiannya terlebih dahulu dengan dokter atau apoteker, terutama jika menderita penyakit tertentu, seperti penyakit jantung.Obat antidiare biasanya tidak terlalu dibutuhkan, kecuali bagi mereka yang memiliki aktivitas padat atau yang ingin bepergian jarak jauh.

Sebagian besar penderita diare sembuh setelah beberapa hari tanpa melakukan pengobatan. Pada orangorang dewasa, diare biasanya sembuh setelah 2-4 hari. Sedangkan pada anak- 
anak, diare biasanya berlangsung lebih lama, yaitu antara 5-7 hari.

Jika anak mengalami diare yang parah, berkelanjutan, atau jika dia mulai menunjukkan tanda-tanda dehidrasi, segera periksakan anak ke dokter. Diare sebanyak enam kali atau lebih dalam jangka waktu 24 jam pada anak juga sebaiknya dikonsultasikan kepada dokter.Begitu juga dengan diare yang membuat kondisi tubuh menurun drastis harus dikonsultasikan kepada dokter, terlebih jika ada darah atau nanah pada tinja.

Pemeriksaan tinja di laboratorium mungkin diperlukan sebagai bagian dari penelitian lebih jauh. Diare yang berlangsung lebih dari beberapa minggu pada orang dewasa bisa diakibatkan oleh sindrom iritasi usus, kanker usus, atau penyakit Crohn.

\section{MATERI DAN METODE PELAKSANAAN}

\section{A. Khalayak Sasaran}

Khalayak sasaran pengabdian masyarakat ini adalah siswa SMA Negeri 2 Kumai dengan perwakilan setiap kelas dengan jumlah sebanyak 55 orang siswa. Kegiatan pendidikan diare diharapkan dilaksanakan sesuai dengan rencana awal dan kepada para peserta pelatihan diberikan materi pendidikan perilaku hidup bersih dan sehat. Penyuluhan dilakukan pada hari selasa, 15 Oktober 2018 pada pukul 08.00 WIB s/d selesai.

\section{B. Metode Kegiatan}

Untuk memecahkan permasalahan yang dihadapi dalam pelatihan ini, maka dipilih beberapa metode pemecahan sebagai berikut :

1. Metode tanya jawab dan ceramah,digunakan pada saat pemberian pendidikan tentang diare.

2. Evaluasi hasil praktik konseling menggunakan pedoman evaluasi yang sudah disiapkan sebelumnya.

\section{A. Hasil}

Hasil kegiatan pengabdian pada masyarakat ini dapat disimpulkan baik. Hal ini dibuktikan dari tanya jawab peserta. Evaluasi hasil penyuluhan meliputi :

1. Banyaknya peserta yang bertanya

2. Pemecahan masalah dalam menyelesaikan sebuah kasus

\section{B. Pembahasan}

Pada penyuluhan pengetahuan tentang diare dengan tujuan memberikan pendidikan kesehatan kepada siswa tentang penyakit diare sehingga seluruh siswa dapat mengatasi dengan tepat bila terjadi diare.

Berdasarkan evaluasi hasil penyuluhan mengenai penyakit diare diperoleh hasil sebagai berikut:

1. Banyaknya yang bertanya, setelah pembicara selesai menyampaikan materi dan dibuka sesi pertanyaan hampir dari $60 \%$ peserta ingin 
bertanyaan, ini menunjukkan bahwa antusias siswa sangat tinggi.

2. Hasil pre dan post test, setelah dilakukan pre dan post test maka didapatkan hasil yang menunjukkan bahwa ada peningkatan pengetahuan.

3. Hasil akhir dari kegiatan ini siswa dapat menjelaskan dengan baik cara untuk mengatasi bila terjadi diare.

\section{SIMPULAN DAN SARAN}

\section{A. Simpulan}

Kegiatan pengabdian kepada masyarakat yang telah dilakukan ini banyak memberikan manfaat terutama dalam meningkatkan pengetahuan, sikap. Selain itu kegiatan pengabdian kepada masyarakat ini dapat dijadikan sebagai sarana untuk meningkatkan keterampilan, pengembangan kreativitas,dan menambah wawasan serta pengetahuan tentang perilaku hidu sertap sehat dan bersih.
B. Saran

Setelah penyuluhan terakhir diharapkan peserta yang telah memperoleh pengetahuan tentang diare dan cara menangani diare bila terkena diare.

\section{DAFTAR PUSTAKA}

Kementerian Kesehatan RI. 2011. Situasi Diare di Indonesia. BuletinJendela Data dan Informasi Kesehatan: Jakarta.

(http://www.depkes.go.id/folder/view/01/structure-publikasipusdatin-buletin.html)

Arief, Mansjoer. 2000. Kapita Selekta Jilid II Edisi 3. Media Aesculapius : Jakarta Dongoes, Mariliynn. 2000. Rencana Asuhan Keperawatan. EGC : Jakarta

Carpenito-moyet, Lynda juall. 2007. Buku

Saku Diagnosis Keperawatan : Jakarta 